\title{
Dietary continuity vs. discontinuity in Bronze Age Italy. The isotopic evidence from Arano di Cellore (Illasi, Verona, Italy)
}

\author{
Alessandra Varalli ${ }^{\mathrm{a}, \mathrm{b}, *}$, Jacopo Moggi-Cecchi ${ }^{\mathrm{b}}$, Irene Dori ${ }^{\mathrm{b}}$, Silvia Boccone ${ }^{\mathrm{b}}$, Silvia Bortoluzzi ${ }^{\mathrm{b}}$, \\ Paola Salzani ${ }^{\mathrm{c}}$, Mary Anne Tafuri ${ }^{\mathrm{d}}$ \\ a Aix-Marseille Université, CNRS, MCC, LAMPEA UMR 7269, 5, rue du Château de l'Horloge, B.P. 647, 13094 Aix-en-Provence, France \\ b Laboratorio di Antropologia, Dipartimento di Biologia, Università degli Studi di Firenze, Via del Proconsolo, 12, 50122 Firenze, Italy \\ c Dipartimento di Lettere e Filosofia, Università degli Studi di Trento, via Tommaso Gar 14, 38122 Trento, Italy \\ d Dipartimento di Biologia Ambientale, Sapienza Università di Roma, P.le A. Moro, 5, 00185 Roma, Italy
}

\section{A R T I C L E I N F O}

\section{Article history:}

Received 16 November 2015

Received in revised form 21 March 2016

Accepted 27 March 2016

Available online $\mathrm{xxx}$

\section{Keywords:}

Stable isotopes

Paleodiet

Oral pathologies

Bronze Age

Northern Italy

\begin{abstract}
A B S T R A C T
This paper explores dietary practices in Bronze Age northern Italy through the isotopic investigation of human and animal collagen from the Early Bronze Age (EBA) necropolis of Arano di Cellore (Illasi, Verona). An earlier study had recently dated to the Bronze Age the introduction of $\mathrm{C}_{4}$ crops in the Po Plain in a way that makes this region of Europe a key area to explore Bronze Age economic strategies. Our study shows that diet at Arano was based on the consumption of $C_{3}$ cereal-type plants, with isotope values clustered in a narrow range: this distribution would indicate a rather homogeneous diet with only slight differences in accordance to sex of the individuals. The evidence from Arano seems to suggest that during the EBA, food consumption was strongly rooted in earlier traditions likely going back to the Neolithic, either in terms of type of crops consumed or relative contribution of plants and animal proteins to the diet. Thanks to the evidence from Arano, we are now able to firmly place the shift in crop use in the region at a transition phase between the late phases of the EBA and the beginning of the MBA. When comparing Arano's results with those from EBA Mediterranean sites similar isotopic patterns are identified. A general uniformity of dietary practices for the south of Europe could be advocated, so that the consumption of $\mathrm{C}_{4}$ plants identified in the Po Plain during the MBA might have been limited to very specific sites. (c) 2016 Elsevier Ltd. All rights reserved.
\end{abstract}

\section{Introduction}

The evolution of Copper and Bronze Age societies in Europe seems to be largely characterized by the development of food production techniques as well as by an increasing social complexity, notwithstanding many regional variants (Harding, 2000; Harding and Fokkens, 2013). The economic choices of farmers and herders, also influenced by social and environmental aspects, can be explored through the investigation of dietary patterns. Southern Europe, and Italy in particular, is characterized by a strong biodiversity and a variety of ecosystems and landscapes: in this perspective the study of human diet is essential to achieve information on the management of food resources and dietary variability within productive economies. This is particularly true for the Po Plain, where isotopic work (Tafuri et al., 2009) has shown that the introduction of $\mathrm{C}_{4}$ crops (millets) dates back to the Middle Bronze Age (MBA) and has proven a great variation in subsistence strategies across areas of the Peninsula. The understanding of mode and time of diffusion of new crops, and the exploration of economic practices during

\footnotetext{
* Corresponding author at: Aix Marseille Université, CNRS, MCC, LAMPEA UMR 7269, 5 , rue du Château de l'Horloge, B.P. 647, 13094 Aix-en-Provence, France.

E-mail address: alessandravaralli@gmail.com (A. Varalli).
}

the Italian Bronze Age calls for a wider isotopic dataset, either in terms of geography or chronology.

In addition to traditional archeological proxies (i.e. coprolites, meal residues, zooarcheological and paleobotanical records), stable isotopic analysis can provide an important contribution to the identification of past dietary patterns and food behavior. The analysis of stable carbon and nitrogen isotopes in bone collagen is routinely conducted to reconstruct the diet and the environment from which individuals draw their resources (e.g. marine vs. terrestrial) and their place in the food web (e.g. herbivore vs. carnivore). Collagen isotopes reflect the protein portion of the diet so that $\delta^{13} \mathrm{C}$ and $\delta^{15} \mathrm{~N}$ of consumers will reflect the $\delta^{13} \mathrm{C}$ and $\delta^{15} \mathrm{~N}$ of food sources. The measurement of $\delta^{13} \mathrm{C}$ and $\delta^{15} \mathrm{~N}$ in human bone collagen can reflect dietary information on the last years of an individual's life, considering an offset of $0.5-1 \%$ or for $\delta^{13} \mathrm{C}$ and $3-4 \%$ for $\delta^{15} \mathrm{~N}$ along the food chain within the same ecosystem (Chisholm et al., 1982; Hedges and Reynard, 2007). The $\delta^{13} \mathrm{C}$ and $\delta^{15} \mathrm{~N}$ measured in animal bone collagen can help in characterizing the isotopic baseline of the foodstuffs and contribute to the reconstruction of the dietary behavior of associated humans (e.g. Bocherens and Drucker, 2003).

Only recently has Italian prehistoric diet been investigated through isotopic analysis (e.g., Lai et al., 2007, 2014; Lelli et al., 2012; Tafuri 
et al., 2009, 2014; Varalli et al., 2015a,b); in this paucity of data we have carried out a stable carbon and nitrogen isotope study on human and animal bone collagen integrated with anthropological data at the necropolis of Arano di Cellore, near the modern town of Illasi (15 km east of Verona) (Fig. 1). The results from Arano can contribute to the creation of a prehistoric isoscape for the Italian Peninsula, especially in consideration of the complex isotopic scenario that is progressively emerging.

\section{Archeological context}

The Early Bronze Age (EBA) site of Arano is one of the most important examples of funerary rites in Northern Italy at the beginning of the 2 nd millennium cal BC. The site, located about $15 \mathrm{~km}$ northeast of the modern town of Verona, includes the most extensive necropolis of Northern Italy dated to the EBA, superimposed on part of a pebble platform dated to the first half of the third millennium BC (Early Copper Age), both excavated in area B. A further area with remains/waste from a settlement (area A) was covered by an isolated burial dated either to a period of transition from the Copper Age to the Bronze Age, or to an initial moment of the Bronze Age (Salzani, 2014).

Out of 73 individuals, 17 were radiocarbon dated, suggesting that the cemetery was probably used over several generations within the first 2 centuries of the 2nd millennium cal BC (Valzolgher et al., 2012). Burial activity was therefore mainly restricted to the phases EBA I B/ EBA I $C$ in the Northern Italian Bronze Age chronology (2040-1890 cal BC) (De Marinis, 1999, Fig. 80; Valzolgher et al., 2012), correlated to the phases $\mathrm{Bz} \mathrm{A} 1 \mathrm{~b}$ and $\mathrm{Bz} \mathrm{A} 2 \mathrm{a}$ of the central European chronology (David, 1998, 2002; David-Elbiali, 2011; David-Elbiali and David, 2009; Mayer, 1977; Ruckdeschel, 1978; Torbrügge, 1959).

The necropolis was excavated in 2007 by the Soprintendenza Archeologica del Veneto in cooperation with the University of Florence (Salzani and Salzani, 2008; Salzani et al., 2015). The necropolis was composed of 61 tombs, mostly containing inhumed in structured graves covered by pebbles, and only one cremation with the burnt bone buried in a pit. Six further structures of uncertain definition with no skeletons were also found (Fig. 2).

The majority of the inhumations at Arano are single burials (53), the multiple burials are eight, of which four with two skeletons and four with three skeletons. The meaning of multiple burials is not clear yet (families? élite?) and it is widely discussed in the archeological study of the site (Salzani, 2014). At present, we know that Early Bronze Age cemeteries in this area show no evidence of multiple burials (e.g. Sorbara di Asola - Mantova, Valserà di Gazzo Veronese - Verona) (Baioni, 2000; Salzani, 1998-1999, 2001), although some exceptions are attested (Via Guidorossi - Parma) (Bernabò Brea and Mazzieri, 2013).

At Arano, the position of the body is contracted, with various degrees of flexion of the limbs. Seventy-three individuals of different age groups were identified, frequently found in anatomical connection.

The bipolar deposition consists in a funerary ritual where the bodies are placed in opposite position (e.g. left vs. right; N vs. S); in this cemetery the deposition is defined sexually: the males are generally placed on the left, the females on the right. The face of the dead looks toward the $\mathrm{W}$, and therefore the heads of the individuals deposed on the right side, mostly feminine, are at the $\mathrm{N}$, whereas those of the individuals deposed on the left, mainly masculine, are at S. Bipolarism occurs also in infant burials for which, however, the sex is determined only in a few cases.

In the multiple graves the bipolar position is given by a superimposition of the bodies at the height of the pelvis and the deposition is never side by side but for one exception. The norm of bipolar deposition has only 5 exceptions. Such a "sexually differentiated bipolar deposition mode" (Harding, 2000:77) has been well documented, e.g. in EBA flat inhumation cemeteries north of the Alps (e.g. Singen am Hohentwiel in Baden-Württemberg, SW Germany [Krause, 1988]; Gemeinlebarn F and Franzhausen I in Lower Austria [Neugebauer, 1991; Neugebauer and Neugebauer, 1997]).

The grave goods of Arano cemetery (Valzolgher et al., 2012: 488, Figs. 4-5) present only in about a quarter of the burials (24\%), are composed mostly of ornamental objects (necklace spacer beads, pendants, 1 metal neck ring in burial 60); these are interpreted as personal objects or decorative elements of the clothes. The two necklace spacer beads from the incineration tomb ( $\mathrm{Tb} 22$ ) have not been exposed to heat, hence they cannot have been on the funeral pyre but were placed in the grave later on.

Contrary to what occurs in most transalpine necropoles, at Arano pottery as grave goods is practically absent, with the exception of a miniature vessel found in the only infant burial with three infant skeletons.

The only non-ornamental objects deposed with the dead are a metal dagger ( $\mathrm{Tb} 21$ ), two perforated bone discs, perhaps in connection with the handle of the ritual dagger in perishable material (wood) in burials 18 and 21, and an arrowhead (Tb 7).

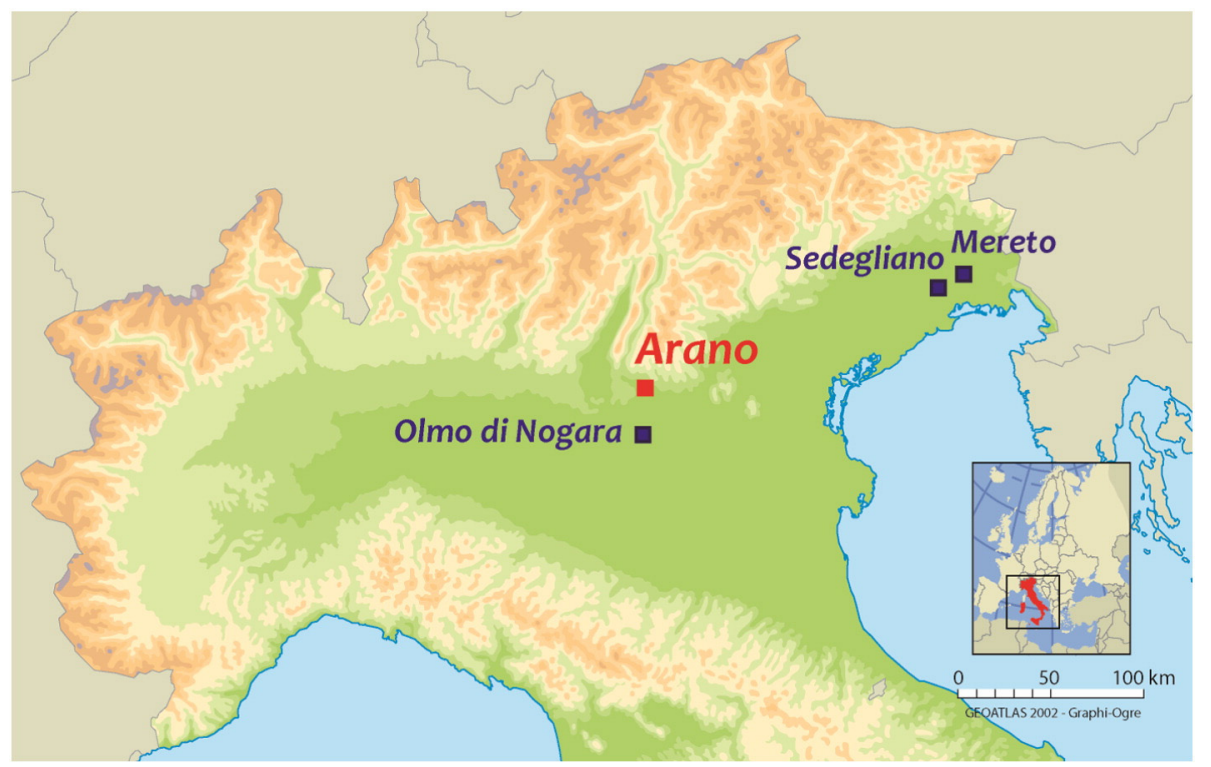

Fig. 1. Map of Northern Italy showing the location of the sites considered: Arano di Cellore (EBA), Sedegliano (EBA), Mereto (EBA) and Olmo di Nogara (MBA). 


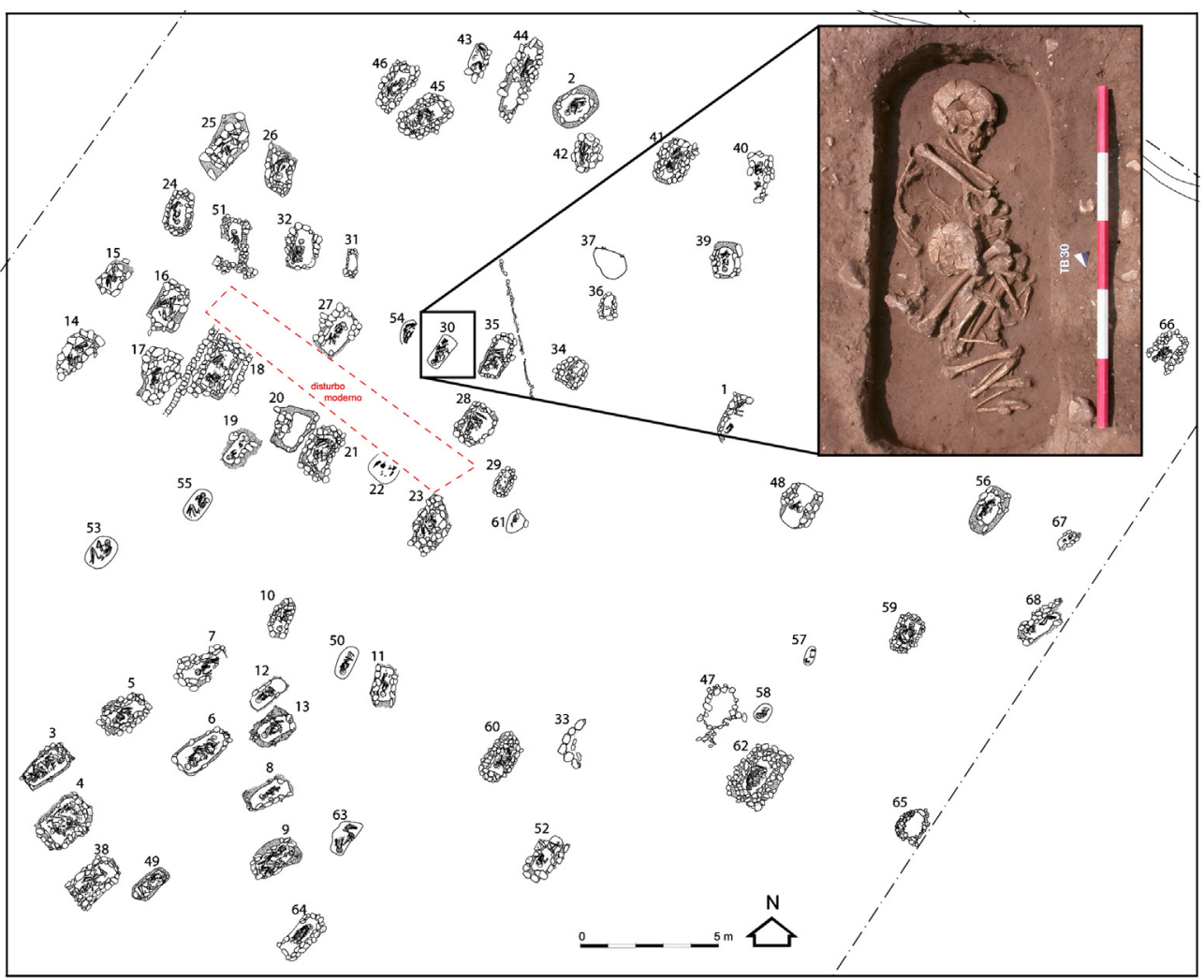

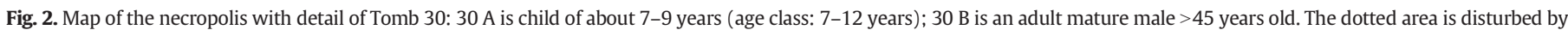
modern interventions.

The distribution of the grave goods comprises all 4 burials with three skeletons, the 2 bipolar burials with two skeletons, the 8 individual burial, as well as $\mathrm{Tb} 22$, the incineration burial. The ornaments (and the pot) seem to be reserved to female individuals or young/infant burials, while the dagger and the bone discs are present only in the burials of male adults.

The importance of the two metal objects of the burials 21 and 60 is not related to the typology of the objects but to their chemical composition. They are not made of bronze $(\mathrm{Cu}+\mathrm{Sn})$ but in Fahlerz (fahlore) with $\mathrm{Ni}$ - copper containing antimony, nickel, arsenic and silver -, and are the only two objects analyzed in the Early Bronze Age in Northern Italy, coming from a closed context, that have this composition together with a certified chronology (Pernicka and Salzani, 2011; Salzani, 2011).

The social structure that emerges from the study of the necropolis of Arano is that of an organized group, given that the bipolar position of the dead is based principally on the difference between males and females. We are therefore dealing with an explicit recognition in the funerary practice of an ascribed status, that is determined by birth and over which one does not have control. As regards the presence of an achieved status (reputation, position, social status), the elements mostly informative are the grave goods with metal objects from burials 21 and 60 , as well as the monumental structure of $\mathrm{Tb} 18$. It is difficult to ascertain the importance of ornamental objects such as the necklace beads and the pendants, that seem to be exclusively in female and infant burials (Parker Pearson, 1999; Salzani, 2014).

\section{Materials and methods}

\subsection{Anthropological analysis}

The skeletons from Arano showed a poor state of preservation. The analysis of the skeletal remains allowed the determination of the sex and age at death for most of the individuals. To this end standard anthropological methods were used (e.g. Ferembach et al., 1980; Meindl and Lovejoy, 1985; Schutkowski, 1993; Smith, 1984; Steckel et al., 2006; Ubelaker, 1989), together with more recent metrical methods of sex determination for adults and subadults (Seidemann et al., 1998; Viciano et al., 2011). Ages at death distribution was assessed for 72 skeletons.

In order to determine the health status and infer on food practices of the Arano group, we focused our skeletal investigation on dental pathological conditions such as caries and hypoplastic defects. Dental caries were analyzed for all subjects with permanent dentition (i.e. older than 10 years, $n=59$ ), whereas enamel defects (hypoplasia), were observed in the permanent teeth (fully mineralized or not) of the entire sample ( $\mathrm{n}=72$ ) (Dori, 2014). Dental caries are in general related to food composition and oral hygiene, while enamel hypoplasia can give information about non-specific conditions of stress occurred during development (e.g. Goodman and Rose, 1990, 1991; Goodman et al., 1980; Rowe, 1982; Hillson, 2001). As for caries, the degree of severity, the surface, and the location on the tooth were recorded. Hypoplastic defects were scored according to Schultz (1988). Frequencies of caries and hypoplastic defects were computed per individual and per tooth. An individual was considered affected when at least one tooth showed presence of caries (or hypoplasia).

\subsection{Stable isotope analysis}

For the isotopic study we have collected 75 samples of bone for collagen extraction: 61 humans and 14 faunal remains, the latter recovered in the close by settlement (area A). Either adult or subadult individuals were selected, with the two sexes among the adults equally represented. The faunal specimens were both domesticates (Bos, Ovis vel Capra, Sus) and wild (Cervus).

We compared the results of the current study with isotopic data obtained at other Bronze Age sites located in the North of Italy, namely 
Olmo di Nogara (Verona), Sedegliano (Udine), and Mereto (Udine) (Tafuri et al., 2009), so as to build a larger isotopic database and explore similarities vs. differences in the region, across time and space (Fig. 1). A further level of comparison included Bronze Age sites from central and southern Europe, with a particular focus on the isotopic evidence of the introduction of new crops.

The samples were prepared at the Dorothy Garrod Laboratory for Isotopic Analysis, McDonald Institute for Archaeological Research, University of Cambridge. Bone collagen extraction followed a modified Longin (1971) method, according to Brown et al. (1988). In brief, approximately $0.5 \mathrm{~g}$ of cortical bone was cleaned by surface abrasion to remove superficial contaminants and demineralized with $0.5 \mathrm{M} \mathrm{HCl}$ for $2-4$ days at $4{ }^{\circ} \mathrm{C}$. The acid was removed through rinsing the samples several times with distilled water. The samples were then gelatinized with $\mathrm{pH} 3$ water at $75^{\circ} \mathrm{C}$ for $48 \mathrm{~h}$. The resulting solution was filtered using an Ezee $^{\mathrm{TM}}$ filter and the supernatant was freeze-dried. Each of the collagen extracts was weighed in triplicate; stable carbon and nitrogen isotope ratios were measured using a Thermo Finnigan Delta Plus XL continuous flow mass spectrometer coupled to a Flash EA 1112 elemental analyzer. ${ }^{1}$

We checked the extracted collagen against several preservation criteria, i.e. collagen yield, carbon and nitrogen content and $\mathrm{C} / \mathrm{N}$ ratio (Van Klinken, 1999; DeNiro, 1985).

\section{Results and discussion}

\subsection{Biological profile of the population}

The number of individuals, sex and age at death distribution are shown in Table 1.

The total sample $(\mathrm{n}=72)$ is composed of 44 mature adults, i.e. over 20 years old ( 31 males and 13 females), and 28 subadults (immature and juvenile individuals, 0-19 years). Among subadults, the sex estimation was possible for only 9 of them. Among adults $70.5 \%$ are males; the small number of female skeletons in the sample is an issue that will require further investigation. In terms of age at death distribution, among subadults the highest mortality is in the group 13-19 years, whereas among adults the highest is in the 20-45 age range. The absence of skeletal remains of fetuses and newborns is possibly related to the generalized marked deterioration of all the skeletal elements.

Tables 2 and 3 show frequencies of the selected dental pathologies in the Arano sample. Caries was examined in 59 subjects with an age over 10 years, and was present in $59.3 \%$ of the sample. All the individuals affected (except Tb. 11 and Tb. 39) are older than 20. No differences in the occurrence of this pathology between males and females have been observed ( $X^{2}$ test: $\mathrm{p}=0.18-$ d.f. $=1$ ). Among the 1388 teeth analyzed, 186 are affected (13.4\%). Caries is present in $13.9 \%$ of the maxillary and in $13 \%$ of the mandibular teeth. The most affected teeth are molars and, in particular, $\mathrm{M}_{1}$ and $\mathrm{M}^{2}$. The highest frequency of caries was recorded in areas where food accumulation is more frequent (interproximal surfaces at the crown cervix).

In the entire skeletal sample, hypoplastic defects have been observed in 52 individuals (72.2\%) with no difference between males, females and indeterminate subjects $\left(X^{2}: p=0.39-\right.$ d.f. $\left.=2\right)$. Among the 1590 teeth analyzed, 487 showed enamel defects (30.6\%). Later developing teeth (canines, premolars and third molars) show higher frequencies of hypoplasia, both in the upper and lower jaws.

\footnotetext{
${ }^{1}$ Carbon and nitrogen isotopic values are reported as the ratio of the heavier isotope to the lighter isotope relative to an internationally defined scale, VPDB for carbon, and AIR for nitrogen. Isotopic results are reported as $\delta$ values $\left(\delta^{13} \mathrm{C}\right.$ and $\left.\delta^{15} \mathrm{~N}\right)$ in units of parts per 1.000 or per mil (\%) values, where $\delta^{15} \mathrm{~N}_{\text {AIR }}=\left[\left({ }^{15 / 14} \mathrm{~N}_{\text {sample }} /{ }^{15 / 14} \mathrm{~N}_{\mathrm{AIR}}\right)-1\right] \times 1.000$. The more positive the $\delta$ value, the more enriched the sample is with the heavier isotope.
}

Table 1

Arano sample composition by sex and age at death.

\begin{tabular}{lccccc}
\hline Age & Males & Females & n.d. & Total & $\%(\mathrm{n}=72)$ \\
\hline $0-6$ & & & 10 & 10 & $13.9 \%$ \\
$7-12$ & 2 & 5 & 7 & $9.7 \%$ \\
$13-19$ & 5 & 2 & 4 & 11 & $15.3 \%$ \\
$20-45$ & 27 & 11 & & 38 & $52.8 \%$ \\
$>45$ & 4 & 2 & & 6 & $8.3 \%$ \\
Total & 38 & 15 & 19 & 72 & $100 \%$ \\
$\%$ & $52.8 \%$ & $20.8 \%$ & $26.4 \%$ & $100 \%$ & \\
\hline
\end{tabular}

\subsection{Diet at Arano di Cellore}

Table 4 presents the values of stable carbon and nitrogen isotopes by skeleton number, sex and age at death, presence/absence of oral pathologies and presence/absence of grave goods; values of the associated fauna are also presented.

For the humans only 58 individuals yielded enough collagen for analysis, while all the 14 animal specimens prepared for extraction could be analyzed. $\mathrm{C} / \mathrm{N}$ ratios obtained, for both animals and humans, fall in the range between 3.1 and 3.3, which indicates good collagen preservation. An exception is represented by one sample (Tb $3 \mathrm{~b}$ ) with a ratio of 4.48 , which was thus excluded from our analysis. Two further samples ( $\mathrm{Tb} 4 \mathrm{a}$ and $\mathrm{Tb} 6 \mathrm{a}$ ) have been excluded because of insufficient $\% \mathrm{C}$ and \% $\mathrm{N}$, while $\mathrm{Tb} 44(12.3 \% \mathrm{C}$ and $4.3 \% \mathrm{~N})$ and $\mathrm{Tb} 64(12.2 \% \mathrm{C}$ and $4.2 \% \mathrm{~N}$ ) have low values, hence data obtained should be treated with caution. A further sample ( $\mathrm{Tb} 4 \mathrm{c}$ ) was discarded because of high standard deviation of the three runs $(0.5 \%$ o). We decided to consider Tb 7 even though the collagen yield is slightly under the accepted limit $(0.9 \%)$ in consideration of reliable \%,$\% \mathrm{C}$ and $\mathrm{C} / \mathrm{N}$. Among the faunal specimens, only one bovid, bos 3 , has been excluded because of the standard deviation $(0.5 \%$ ). As a result, 54 human samples and 13 faunal specimens have been considered for data analysis and interpretation. The $\delta^{13} \mathrm{C}$ of human samples ranges between $-20.9 \%$ and $-19.7 \%$ 。 with a mean of $-20.2 \%$, while the $\delta^{15} \mathrm{~N}$ of human sample ranges between $6.9 \%$ and $8.9 \%$ with a mean of $7.9 \%$. The mean $\delta^{13} \mathrm{C}$ and $\delta^{15} \mathrm{~N}$ values of herbivorous mammals - respectively sheep/goat, cattle, and deer - are: $-19.9 \%$ and $4.2 \%,-19.2 \%$ and $4.3 \%$, and $-18.7 \%$ and $4.3 \%$. The mean $\delta^{13} \mathrm{C}$ and $\delta^{15} \mathrm{~N}$ values of the pigs are: $-20.5 \%$ and $4.7 \%$ o (Table 4 ).

The data obtained for the animals fall within the range of terrestrial $\mathrm{C}_{3}$ plant consumers (Fig. 3). In general, faunal data obtained are fairly uniform, and there is no significant discrepancy between exclusively herbivorous animals (sheep/goats, cattle and deer), and those with mixed diet, such as pigs. Thus, no distinction in dietary pattern is highlighted considering the traditional categories of browsers, grazers and omnivores. Furthermore, similar ranges of $\delta{ }^{15} \mathrm{~N}$ and $\delta^{13} \mathrm{C}$ are obtained for the domestic and wild fauna, suggesting as the foraging of domestic animals was based on the same products of local wild species. This evidence is confirmed by statistical analysis as no significant differences appear among the groups of the four species (Kruskal Wallis test, $\mathrm{H}=$ 0.22 ; $\mathrm{p}=0.9$ for $\delta^{15} \mathrm{~N}$ and $\mathrm{H}=3.97 ; \mathrm{p}=0.2$ for $\delta^{13} \mathrm{C}$ ). Interestingly, the pigs have the same $\delta^{15} \mathrm{~N}$ value of the herbivores (ranges from $2.8 \%$ o to $6.1 \%$ ), probably indicating that they had a mainly vegetarian diet. Also, the pigs show the most depleted $\delta^{13} \mathrm{C}$ values (from $-20.8 \%$ 。 to $-20.2 \%$ ) with a narrow range $(0.6 \%$ o), mirroring the patterns shown by the humans, probably indicative of a consumption of similar kind of foods. By contrast, the other animals show wider ranges (caprovid: $1.5 \%$, deers: $2.6 \%$, cattle: $2.5 \%$ o). Looking at the cattle samples only, bos 4 shows higher nitrogen isotopic values (5.8\%) within its species; similarly, a deer (cervus 1 ) has a nitrogen value of $5.3 \%$, interestingly, it also shows enriched $\delta^{13} \mathrm{C}$, that is discordant from that of the domestic species. This aspect might reflect the frequentation of an open environment, probably richer in $\mathrm{C}_{4}$ plants, which is coherent with the reconstruction proposed for the Bronze Age Po Plain 
Table 2

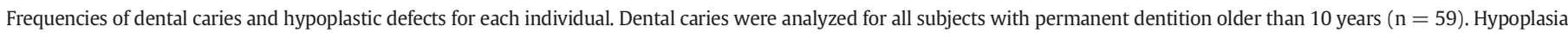
were observed in the permanent teeth of the entire sample $(n=72)$.

\begin{tabular}{|c|c|c|c|c|c|c|c|c|}
\hline & \multicolumn{2}{|c|}{ Males $(\mathrm{n}=38)$} & \multicolumn{2}{|c|}{ Females $(\mathrm{n}=15)$} & \multicolumn{2}{|c|}{ n.d. $(n=6)$} & \multicolumn{2}{|c|}{ tot $(n=59)$} \\
\hline & $\mathrm{n}$ & $\%$ & $\mathrm{n}$ & $\%$ & $\mathrm{n}$ & $\%$ & $\mathrm{n}$ & $\%$ \\
\hline \multirow[t]{3}{*}{ Caries } & 23 & 60.5 & 12 & 80 & 0 & 0 & 35 & 59.3 \\
\hline & \multicolumn{2}{|c|}{ Males $(\mathrm{n}=38)$} & \multicolumn{2}{|c|}{ Females $(\mathrm{n}=15)$} & \multicolumn{2}{|c|}{ n.d. $(\mathrm{n}=19)$} & \multicolumn{2}{|c|}{ tot $(\mathrm{n}=72)$} \\
\hline & $\mathrm{n}$ & $\%$ & $\mathrm{n}$ & $\%$ & $\mathrm{n}$ & $\%$ & $\mathrm{n}$ & $\%$ \\
\hline Hypoplastic defects & 30 & 78.9 & 10 & 66.7 & 12 & 63.1 & 52 & 72.2 \\
\hline
\end{tabular}

(Cremaschi et al., 2006). These two samples are in any case included in the range of isotopic data for prehistoric animals from the north of Italy (Varalli et al., 2015a) and as such have been included in this study.

The comparison between animal and human values from the site of Arano $\left(\Delta^{13} C_{\text {human-fauna }}=0.5 \%\right.$; $\Delta{ }^{15} \mathrm{~N}_{\text {human-fauna }}=3.5 \%$ o $)$ indicates a mixed terrestrial diet (meat or dairy products and vegetal foodstuffs). Furthermore, both stable isotope values and isotopic enrichments highlight that most of the protein consumed by humans came from the local terrestrial ecosystem. No marine and/or freshwater resources seem to have been regularly consumed by this human group, as well as elsewhere in the region (Tafuri et al., 2009). This is particularly interesting, given that the Po Plain was at the time (and in certain areas still is) interested by many watercourses, mostly used for irrigation. It becomes essential to further explain if the lack of isotopic evidence of consumption of freshwater resources is due to a specific dietary choice of these groups or rather to such consumption being isotopically invisible (either because of limited isotopic variation of freshwater species or because of low detectability due to occasional consumption). In general, the $\delta^{13} \mathrm{C}$ and $\delta^{15} \mathrm{~N}$ ranges from human remains showed that the vegetal intake of this community was based on $C_{3}$ cereal-type resources, typical of the so-called "Neolithic package" basically consisting of barley and wheat, as documented in Canàr, in the same region, in this period (Castiglioni et al., 1998). We cannot exclude the possibility that $C_{4}$ plants were consumed, as $\mathrm{C}_{4}$ species are not infrequent in the region for this period (M. Rottoli pers. comm.) however if so not at levels detectable isotopically.

The overall isotopic values - included in a narrow range for both $\mathrm{C}$ and $\mathrm{N}$ - indicate that the Arano group had a rather homogeneous diet. The range of $\delta^{13} \mathrm{C}$ values is fairly low $(\Delta=1.2 \%$ ), probably suggesting that the resources consumed came from foods characterized by a low isotopic range. The range of $\delta^{15} \mathrm{~N}$ values $(\Delta=2.0 \%$ ) is consistent with

Table 3

Frequencies of caries and hypoplastic defects per tooth.

\begin{tabular}{|c|c|c|c|c|c|c|c|c|}
\hline & \multicolumn{2}{|c|}{$\begin{array}{c}\text { Teeth } \\
(\mathrm{n}=59)\end{array}$} & \multicolumn{2}{|c|}{ Caries } & \multicolumn{2}{|c|}{$\begin{array}{c}\text { Tooth } \\
(\mathrm{n}=72)\end{array}$} & \multicolumn{2}{|c|}{ Hypoplasia } \\
\hline & & $\mathrm{n}$ & $\mathrm{n}$ & $\%$ & & $\mathrm{n}$ & $\mathrm{n}$ & $\%$ \\
\hline \multirow[t]{8}{*}{ Upper teeth } & I1 & 78 & 3 & 3.8 & I1 & 95 & 16 & 16.8 \\
\hline & $\mathrm{I} 2$ & 79 & 3 & 3.8 & $\mathrm{I} 2$ & 95 & 21 & 22.1 \\
\hline & $\mathrm{C}$ & 95 & 12 & 12.6 & C & 111 & 54 & 48.6 \\
\hline & P1 & 95 & 13 & 13.7 & P1 & 111 & 41 & 36.9 \\
\hline & P2 & 92 & 10 & 10.9 & P2 & 99 & 31 & 31.3 \\
\hline & M1 & 88 & 17 & 19.3 & M1 & 110 & 4 & 3.6 \\
\hline & M2 & 82 & 21 & 25.6 & M2 & 93 & 27 & 29.0 \\
\hline & M3 & 69 & 15 & 21.7 & M3 & 69 & 31 & 44.9 \\
\hline Total & & 678 & 94 & 13.9 & & 783 & 225 & 28.7 \\
\hline \multirow[t]{8}{*}{ Lower teeth } & I1 & 72 & 1 & 1.4 & I1 & 86 & 12 & 14.0 \\
\hline & $\mathrm{I} 2$ & 83 & 5 & 6.0 & I2 & 100 & 25 & 25.0 \\
\hline & $C$ & 100 & 4 & 4.0 & C & 117 & 62 & 53.0 \\
\hline & P1 & 97 & 11 & 11.3 & P1 & 107 & 46 & 43.0 \\
\hline & P2 & 93 & 7 & 7.5 & P2 & 99 & 48 & 48.5 \\
\hline & M1 & 99 & 27 & 27.3 & M1 & 120 & 10 & 8.3 \\
\hline & M2 & 95 & 22 & 23.2 & M2 & 107 & 28 & 26.2 \\
\hline & M3 & 71 & 15 & 21.1 & M3 & 71 & 31 & 43.7 \\
\hline Total & & 710 & 92 & 13.0 & & 807 & 262 & 32.5 \\
\hline
\end{tabular}

values recorded for a human group characterized by an omnivorous diet (O'Connell and Hedges, 1999). It is interesting to notice how nitrogen and carbon human values, compared to animal ones, are less spread. Particularly, the $\delta^{13} \mathrm{C}$ seems to suggest that some animals (two of the cows and the deer) might have had access to $C_{4}$ plants and that either human diets 'averaged' the animal values, or that the animals enriched in ${ }^{13} \mathrm{C}$ and/or ${ }^{15} \mathrm{~N}$ contributed in small or no part to the human diet. Considering human and animal results we cannot exclude that animals like pigs represented the main animal intake. Albeit zooarcheological data show that the livestock were mainly represented by cattle, sheep and goat during the Early Bronze Age (De Grossi Mazzorin and Solinas, 2013), some sites attested the importance of pigs - between $45 \%$ and 50\% ca. (i.e. Lucone-area D- and Canàr) (Bona, 2011; Riedel, 1998; De Grossi Mazzorin and Solinas, 2013, Table 1, pp. 155). For the site of Arano the zooarcheological study is in progress, it will be interesting to compare faunal data with isotopic results.

When considering the skeletal information, $\delta^{15} \mathrm{~N}$ of the males $(\mathrm{n}=$ 32 ) have a slightly broader range than that of females $(n=12)(\Delta=$ $2.0 \%$ 。v. $\Delta=1.0 \%$ ), which might suggest that males had a more varied diet, however, such difference is not statistically significant (MannWhitney U test: $\mathrm{p}=0.88, \mathrm{U}=186$ ). Similarly, no isotopic differences are highlighted considering males $(n=7)$ and females $(n=2)$ in subadults. According to archeological data, some categories can be identified: the Mann-Whitney U test demonstrates that there are no significant differences between values of individuals with or without grave goods $(U=235.5, p=0.52)$, or in relation to orientation of the burial (North vs. South, $U=357.5, p=0.79$ ) or side of deposition (right vs. left, $U=314, p=0.86$ ). Although a number of studies in the Mediterranean support the hypothesis of differential access to food resources within Bronze Age communities (cf. Hamilakis, 1996), our data seem to be indicative of a community where no readable differences in food consumption occurred. As an example, individuals $\mathrm{Tb} 60$, buried with a torquez, and $\mathrm{Tb} 21$, buried with a dagger, as well as $\mathrm{Tb} 18$, buried in a monumental funerary structure, show $\mathrm{C}$ and $\mathrm{N}$ values in line with those of the rest of the community.

The high frequency of caries observed in the Arano skeletal sample seems to suggest a diet rich in carbohydrates, in line with the results of the isotopic analysis - although other possible causes, such as a poor oral hygiene cannot be ruled out. A similar occurrence of caries in the adult male and female sub-samples, could also suggest the lack of substantial disparities in access to dietary resources, as the isotopic study seems to indicate. When combining caries and isotope data, no statistically significant differences emerge $\left(\delta^{15} \mathrm{~N}, \mathrm{U}=246.5, \mathrm{p}=0.06\right.$; $\delta^{13} \mathrm{C}, \mathrm{U}=280.5, \mathrm{p}=0.21$ ).

Dental enamel hypoplasia is present with high frequencies in the Arano necropolis. Hypoplasia is usually considered to be a non-specific indicator of stress (Nikiforuk and Fraser, 1981), with different origins, such as nutritional deficiencies, infections, metabolic disorders and diseases (e.g. Brothwell, 1963; El-Najjar et al., 1978; Rose, 1977; Skinner and Goodman, 1992). In our sample these defects are located mainly on canines and premolars of both jaws, suggesting that the stress episodes causing them might have occurred between 2 and 5 years of age, the 
Table 4

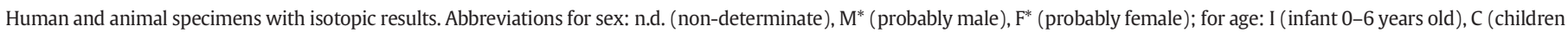
7-12 years old), a (adolescent 13-19 years old), A (adult 20-45 years old), MA (mature adult $>45$ years old).

\begin{tabular}{|c|c|c|c|c|c|c|c|c|c|c|c|c|c|c|}
\hline Sample code & Species & Sex & Age & Hypoplasia & Caries & Grave goods & Collagen (\%) & $\delta^{13} \mathrm{C}$ & C (\%) & Std $\operatorname{dev} C$ & $\delta^{15} \mathrm{~N}$ & $\mathrm{~N}(\%)$ & Std dev N & $\mathrm{C} / \mathrm{N}$ \\
\hline Tb $1 \mathrm{a}$ & Human & n.d. & I & $\mathrm{X}$ & & None present & 6.3 & -20.3 & 26 & 0.02 & 7.1 & 9 & 0.03 & 3.2 \\
\hline $\mathrm{Tb} 2$ & Human & M & $\mathrm{a}$ & $\mathrm{X}$ & & None present & 2.3 & -20.4 & 13 & 0.02 & 6.9 & 4 & 0.01 & 3.3 \\
\hline $\mathrm{Tb} 3 \mathrm{a}$ & Human & $\mathrm{F}$ & A & & $\mathrm{X}$ & Flint arrowhead (?) & 2.2 & -20.0 & 36 & 0.02 & 8.4 & 13 & 0.02 & 3.2 \\
\hline $\mathrm{Tb} 4 \mathrm{~b}$ & Human & $\mathrm{F}^{*}$ & $\mathrm{a}$ & $\mathrm{X}$ & & Ornaments (Dentalium) & 4.5 & -19.7 & 39 & 0.02 & 8.0 & 14 & 0.04 & 3.2 \\
\hline Tb 5 & Human & n.d. & $\mathrm{a}$ & $\mathrm{X}$ & & None present & 3.2 & -20.0 & 34 & 0.03 & 7.5 & 12 & 0.05 & 3.2 \\
\hline $\mathrm{Tb} 6 \mathrm{~b}$ & Human & n.d. & $\mathrm{a}$ & $\mathrm{X}$ & & Ornaments (Dentalium) & 2.8 & -20.3 & 37 & 0.02 & 7.7 & 13 & 0.05 & 3.2 \\
\hline $\mathrm{Tb} 7$ & Human & $\mathrm{M}^{*}$ & A & & $\mathrm{X}$ & None present & 0.9 & -20.0 & 29 & 0.09 & 8.1 & 10 & 0.12 & 3.4 \\
\hline $\mathrm{Tb} 9 \mathrm{a}$ & Human & M & MA & $\mathrm{X}$ & $\mathrm{X}$ & None present & 2.6 & -20.3 & 29 & 0.06 & 7.9 & 10 & 0.05 & 3.3 \\
\hline $\mathrm{Tb} 9 \mathrm{~b}$ & Human & n.d. & $\mathrm{C}$ & $\mathrm{X}$ & & Ornaments (Dentalium) & 2.3 & -20.4 & 43 & 0.02 & 7.6 & 15 & 0.01 & 3.3 \\
\hline Tb 10 & Human & $\mathrm{M}^{*}$ & $\mathrm{a}$ & $\mathrm{X}$ & & None present & 2.4 & -20.5 & 40 & 0.02 & 7.6 & 14 & 0.03 & 3.2 \\
\hline Tb 11 & Human & $\mathrm{M}^{*}$ & $\mathrm{a}$ & $\mathrm{X}$ & $\mathrm{X}$ & None present & 4.6 & -20.2 & 39 & 0.03 & 7.7 & 14 & 0.07 & 3.2 \\
\hline Tb 12 & Human & $\mathrm{M}^{*}$ & C & $\mathrm{X}$ & & None present & 5.8 & -20.3 & 38 & 0.02 & 7.6 & 13 & 0.01 & 3.2 \\
\hline Tb 13 & Human & $\mathrm{M}^{*}$ & $\mathrm{a}$ & $\mathrm{X}$ & & None present & 3.1 & -20.1 & 17 & 0.05 & 8.2 & 6 & 0.16 & 3.3 \\
\hline Tb 14 & Human & M & A & $\mathrm{X}$ & $\mathrm{X}$ & None present & 3.2 & -20.1 & 32 & 0.03 & 8.1 & 11 & 0.02 & 3.2 \\
\hline $\mathrm{Tb} 15$ & Human & $\mathrm{F}^{*}$ & A & & $\mathrm{X}$ & None present & 3.0 & -20.1 & 43 & 0.02 & 8.2 & 15 & 0.05 & 3.2 \\
\hline $\mathrm{Tb} 16 \mathrm{~b}$ & Human & $\mathrm{F}^{*}$ & A & $\mathrm{X}$ & $\mathrm{X}$ & Ornaments (Dentalium) & 4.0 & -20.2 & 17 & 0.01 & 8.0 & 6 & 0.06 & 3.3 \\
\hline Tb 17 & Human & n.d. & $\mathrm{a}$ & $\mathrm{X}$ & & None present & 4.3 & -19.9 & 40 & 0.01 & 8.3 & 14 & 0.05 & 3.2 \\
\hline Tb 18 & Human & $\mathrm{M}$ & A & $\mathrm{X}$ & & Bone tool & 3.9 & -20.2 & 16 & 0.05 & 6.9 & 5 & 0.11 & 3.2 \\
\hline Tb 21 & Human & M & A & $\mathrm{X}$ & $\mathrm{X}$ & Dagger & 8.4 & -20.0 & 40 & 0.02 & 8.4 & 14 & 0.02 & 3.2 \\
\hline Tb 23 & Human & $\mathrm{F}$ & A & & $\mathrm{X}$ & None present & 2.8 & -20.2 & 37 & 0.02 & 7.9 & 13 & 0.05 & 3.2 \\
\hline Tb 24 & Human & M & A & $\mathrm{X}$ & $\mathrm{X}$ & None present & 6.8 & -20.3 & 41 & 0.01 & 8.5 & 15 & 0.05 & 3.2 \\
\hline Tb 25 & Human & M & A & $\mathrm{X}$ & & None present & 2.5 & -20.3 & 40 & 0.01 & 8.5 & 14 & 0.04 & 3.2 \\
\hline $\mathrm{Tb} 26$ & Human & M & A & & $\mathrm{X}$ & None present & 3.7 & -20.3 & 41 & 0.09 & 8.6 & 14 & 0.02 & 3.2 \\
\hline Tb 28 & Human & M & A & $\mathrm{X}$ & $\mathrm{X}$ & None present & 4.6 & -20.3 & 39 & 0.02 & 7.4 & 14 & 0.08 & 3.2 \\
\hline $\mathrm{Tb} 30 \mathrm{~b}$ & Human & $\mathrm{M}^{*}$ & MA & $\mathrm{X}$ & $\mathrm{X}$ & None present & 4.0 & -20.2 & 41 & 0.02 & 7.6 & 14 & 0.04 & 3.2 \\
\hline Tb 34 & Human & n.d. & $\mathrm{C}$ & $\mathrm{X}$ & & None present & 4.2 & -20.2 & 44 & 0.02 & 7.6 & 16 & 0.06 & 3.2 \\
\hline Tb 35 & Human & $\mathrm{M}$ & A & & $\mathrm{X}$ & None present & 2.0 & -20.2 & 30 & 0.02 & 7.8 & 10 & 0.05 & 3.3 \\
\hline Tb 38 & Human & M & A & & $\mathrm{X}$ & None present & 1.9 & -19.8 & 15 & 0.06 & 8.0 & 5 & 0.03 & 3.3 \\
\hline Tb 39 & Human & $\mathrm{M}^{*}$ & $\mathrm{C}$ & $\mathrm{X}$ & $\mathrm{X}$ & None present & 2.3 & -20.3 & 36 & 0.02 & 8.0 & 12 & 0.02 & 3.2 \\
\hline $\mathrm{Tb} 40$ & Human & $\mathrm{F}$ & A & $\mathrm{X}$ & $\mathrm{X}$ & None present & 3.6 & -20.3 & 26 & 0.02 & 7.9 & 9 & 0.03 & 3.3 \\
\hline $\mathrm{Tb} 41$ & Human & M & A & $\mathrm{X}$ & $\mathrm{X}$ & None present & 3.4 & -20.1 & 20 & 0.04 & 8.1 & 7 & 0.08 & 3.3 \\
\hline $\mathrm{Tb} 42$ & Human & $\mathrm{M}^{*}$ & A & $X$ & $\mathrm{X}$ & None present & 3.1 & -20.5 & 25 & 0.03 & 8.0 & 9 & 0.08 & 3.3 \\
\hline Tb 43 & Human & $\mathrm{M}^{*}$ & MA & $\mathrm{X}$ & $\mathrm{X}$ & None present & 3.1 & -20.1 & 29 & 0.04 & 8.0 & 10 & 0.13 & 3.2 \\
\hline Tb 44 & Human & $\mathrm{M}$ & A & $\mathrm{X}$ & $\mathrm{X}$ & None present & 2.1 & -20.2 & 12 & 0.03 & 7.6 & 4 & 0.20 & 3.3 \\
\hline Tb 45 & Human & $\mathrm{M}^{*}$ & MA & & $\mathrm{X}$ & None present & 2.7 & -20.5 & 38 & 0.01 & 7.6 & 13 & 0.07 & 3.3 \\
\hline Tb 46 & Human & $\mathrm{F}$ & A & $\mathrm{X}$ & $\mathrm{X}$ & None present & 2.4 & -20.6 & 36 & 0.03 & 7.6 & 13 & 0.03 & 3.2 \\
\hline Tb 48 & Human & M & $\mathrm{a}$ & $\mathrm{X}$ & & None present & 5.3 & -20.0 & 46 & 0.00 & 8.5 & 16 & 0.04 & 3.2 \\
\hline Tb 49 & Human & $\mathrm{F}^{*}$ & $\mathrm{a}$ & $\mathrm{X}$ & & Ornaments (bracelet) & 1.8 & -20.0 & 24 & 0.05 & 7.6 & 8 & 0.01 & 3.2 \\
\hline Tb 50 & Human & n.d. & $\mathrm{C}$ & $\mathrm{X}$ & & None present & 3.0 & -20.3 & 38 & 0.03 & 7.6 & 14 & 0.09 & 3.2 \\
\hline Tb 51 & Human & $\mathrm{F}^{*}$ & A & $\mathrm{X}$ & $\mathrm{X}$ & None present & 9.0 & -20.3 & 36 & 0.01 & 7.6 & 13 & 0.03 & 3.2 \\
\hline Tb 52 & Human & $\mathrm{M}^{*}$ & A & $\mathrm{X}$ & $\mathrm{X}$ & None present & 2.1 & -20.5 & 14 & 0.01 & 7.8 & 5 & 0.18 & 3.3 \\
\hline Tb 53 & Human & $\mathrm{M}$ & $\mathrm{A}$ & & $\mathrm{X}$ & Flint arrowhead (?) & 3.7 & -20.3 & 38 & 0.05 & 7.3 & 13 & 0.04 & 3.2 \\
\hline Tb 54 & Human & n.d. & $\mathrm{a}$ & $\mathrm{X}$ & & None present & 2.0 & -20.3 & 35 & 0.06 & 8.0 & 12 & 0.10 & 3.3 \\
\hline Tb 55a & Human & $\mathrm{F}^{*}$ & A & $\mathrm{X}$ & $\mathrm{X}$ & None present & 2.5 & -20.4 & 47 & 0.00 & 7.8 & 17 & 0.03 & 3.2 \\
\hline $\mathrm{Tb} 55 \mathrm{~b}$ & Human & n.d. & I & & & None present & 4.3 & -20.4 & 41 & 0.01 & 7.6 & 14 & 0.06 & 3.2 \\
\hline Tb 56 & Human & $\mathrm{M}^{*}$ & A & $\mathrm{X}$ & & None present & 8.5 & -19.9 & 48 & 0.03 & 8.3 & 17 & 0.01 & 3.2 \\
\hline Tb 57 & Human & n.d. & I & & & None present & 4.5 & -20.1 & 40 & 0.05 & 7.9 & 14 & 0.04 & 3.2 \\
\hline Tb 58 & Human & $\mathrm{M}^{*}$ & A & $\mathrm{X}$ & $\mathrm{X}$ & None present & 2.5 & -20.5 & 39 & 0.02 & 7.7 & 14 & 0.06 & 3.2 \\
\hline Tb 59 & Human & $\mathrm{F}^{*}$ & MA & $\mathrm{X}$ & $\mathrm{X}$ & None present & 5.2 & -20.4 & 43 & 0.00 & 8.6 & 15 & 0.04 & 3.2 \\
\hline $\mathrm{Tb} 60$ & Human & $\mathrm{F}$ & A & & $\mathrm{X}$ & Ornaments (torquez) & 9.3 & -20.4 & 42 & 0.00 & 8.1 & 15 & 0.03 & 3.2 \\
\hline Tb 62 & Human & M & A & $\mathrm{X}$ & & None present & 6.1 & -20.1 & 40 & 0.02 & 8.3 & 14 & 0.04 & 3.2 \\
\hline $\mathrm{Tb} 64$ & Human & $\mathrm{M}^{*}$ & A & $\mathrm{X}$ & $\mathrm{X}$ & None present & 3.7 & -20.3 & 12 & 0.01 & 8.9 & 4 & 0.16 & 3.4 \\
\hline Tb 66 & Human & M & $\mathrm{A}$ & $\mathrm{X}$ & $\mathrm{X}$ & None present & 6.0 & -20.9 & 39 & 0.06 & 8.4 & 14 & 0.03 & 3.2 \\
\hline Tb 68 & Human & $\mathrm{M}^{*}$ & A & $\mathrm{X}$ & & None present & 2.8 & -20.3 & 13 & 0.05 & 7.0 & 4 & 0.05 & 3.3 \\
\hline bos 1 & Bos & & & & & & 3.6 & -18.6 & 36 & 0.03 & 2.9 & 13 & 0.03 & 3.2 \\
\hline bos 2 & Bos & & & & & & 5.0 & -20.7 & 39 & 0.06 & 5.8 & 14 & 0.04 & 3.3 \\
\hline bos 4 & Bos & & & & & & 3.8 & -18.2 & 25 & 0.02 & 4.2 & 9 & 0.04 & 3.3 \\
\hline cervus 1 & Cervus & & & & & & 3.6 & -17.4 & 47 & 0.00 & 5.3 & 17 & 0.04 & 3.2 \\
\hline cervus 2 & Cervus & & & & & & 4.7 & -20.0 & 30 & 0.02 & 3.2 & 11 & 0.01 & 3.2 \\
\hline sus 1 & Sus & & & & & & 4.8 & -20.8 & 39 & 0.01 & 4.7 & 13 & 0.01 & 3.3 \\
\hline sus 2 & Sus & & & & & & 4.3 & -20.4 & 24 & 0.00 & 4.6 & 8 & 0.06 & 3.2 \\
\hline sus 3 & Sus & & & & & & 2.7 & -20.6 & 46 & 0.03 & 4.7 & 16 & 0.01 & 3.3 \\
\hline sus 4 & Sus & & & & & & 6.4 & -20.3 & 41 & 0.02 & 6.1 & 15 & 0.03 & 3.2 \\
\hline sus 5 & Sus & & & & & & 4.2 & -20.2 & 37 & 0.01 & 3.6 & 13 & 0.01 & 3.2 \\
\hline C_o_1 & Ovis vel capra & & & & & & 7.2 & -19.2 & 39 & 0.02 & 4.9 & 14 & 0.02 & 3.2 \\
\hline c_o_2 & Ovis vel capra & & & & & & 5.4 & -19.6 & 31 & 0.04 & 4.8 & 11 & 0.02 & 3.2 \\
\hline c_o_3 & Ovis vel capra & & & & & & 4.4 & -20.7 & 45 & 0.04 & 2.8 & 16 & 0.05 & 3.2 \\
\hline
\end{tabular}

time frame of enamel formation in these teeth. The occurrence of these defects could be likely linked to a change in food type after weaning, with a transition to an adult diet of poor quality, preferably represented by carbohydrates. However, no significant differences in $\delta{ }^{15} \mathrm{~N}$ and $\delta^{13} \mathrm{C}$ have been detected between individuals affected by hypoplasia and not $\left(\delta^{15} \mathrm{~N}, \mathrm{U}=220, \mathrm{p}=0.51 ; \delta^{13} \mathrm{C}, \mathrm{U}=216, \mathrm{p}=0.46\right)$. 


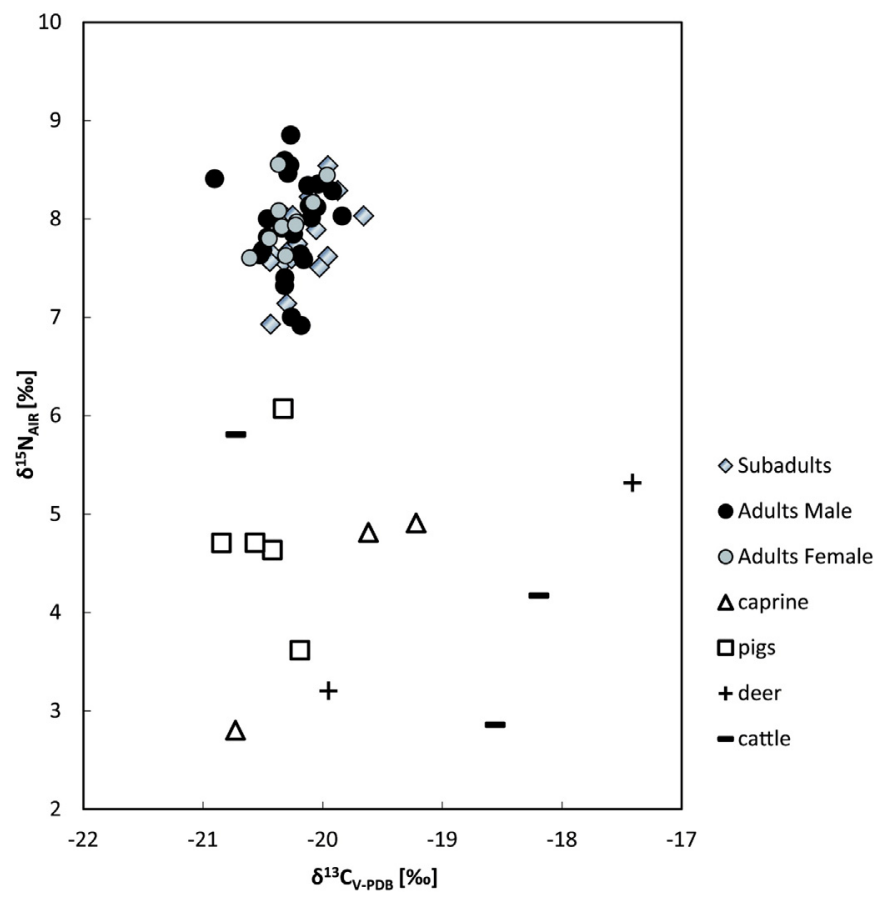

Fig. 3. Stable carbon and nitrogen isotope data of human and animal bone collagen from Arano. Subadult, Male, Female and unknown sex adults are indicated.

\subsection{Millet consumption in the Bronze Age Po Plain}

The introduction and diffusion of domestic plants in Italy have been relatively well documented (e.g. Fiorentino et al., 2004; Mercuri et al., 2006; Nisbet and Rottoli, 1997) and are the subjects of ongoing debate. As an example, according to Fiorentino et al. (2004), with the beginning of the 2nd millennium BC farming in northern Italy appears markedly more developed, while others assume that agriculture does not undergo any significant variation if through a growth of importance of hulled wheat (einkorn, emmer and spelt) and "poor cereals" such as Panicum miliaceum (broomcorn millet), Setaria italica (foxtail millet), Avena sativa (oats) and Secale cereale (rye) (Marzatico, 2009; Nisbet, 1992, 1996, 2004). Despite archeobotanical investigation confirming the presence of P. miliaceum across Europe and west Asia prior to $5000 \mathrm{BC}$ (Hunt et al., 2008), the regular consumption of this crop, such to be isotopically visible, occurred definitely later, probably not earlier than the Bronze Age. Archeobotanical evidence suggests the sporadic presence of the millets in northern Italy already during the Neolithic, i.e. at Isolino Virginia (VA), Sammardenchia (UD), Piancada (UD), and Levata di Curtatone (MN) (Carra, 2012; Forni, 1979; Rottoli, 2007), however no isotopic results support a significant introduction of these crops in the diet (e.g. Goude, 2007).

With millets having distinctively different isotopic signatures for carbon, isotopic analysis has helped in assessing the relative contribution of $C_{3}$ and $C_{4}$ plants to the Bronze Age human diet. Recent isotopic evidence (Tafuri et al., 2009) has demonstrated that northern Italy is a key area to understand dietary complexity during the Bronze Age in Europe. Not only such records have pre-dated the introduction of $C_{4}$ crops in Italy already at the middle phases of the Bronze Age, but have revealed a substantial difference in plant use between Northern and Southern Italian regions. Further works have confirmed the use of $C_{4}$ plants in Central and Southern Europe during the Bronze Age (Lightfoot et al., 2013), although the use of the millets is believed to be mostly sporadic, with only a few sites showing significant consumption, namely Ramnyo, in Greece (Triantaphyllou, 2001) and Olmo di Nogara itself.
Results obtained at Olmo di Nogara (Verona) (MBA) and Sedegliano (Udine) (EBA) displayed isotopic values enriched in ${ }^{13} \mathrm{C}$. Tafuri et al. (2009) suggested that marine resources consumption, which could potentially explain the higher $\delta^{13} \mathrm{C}$ values, was extremely unlikely for both sites, also in consideration of low $\delta^{15} \mathrm{~N}$, that was inconsistent with data traditionally recorded when fish consumption is testified (e.g. Richards and Hedges, 1999; Dufour et al., 1999). Carbon and nitrogen data were consistent with significant or occasional consumption of domestic millets ( $P$. miliaceum and/or S. italica), all $\mathrm{C}_{4}$ crops. The exploitation of indigenous wild $\mathrm{C}_{4}$ species (e.g. Echinochloa crus-galli) was excluded considering that the irregular consumption of these plants would not have been registered at isotopic levels. The analysis of macroremains suggests that there was a food interest for this species only in one site in the Bronze Age (Castellaro del Vhò, Cremona) (Rottoli, 2001). When Arano isotopic results are compared with these Early to Middle Bronze Age sites interesting differences emerge (Fig. 4). Our results contribute to define a complex pattern in food practices for this area of the Peninsula at the transition between the Early and Middle Bronze Age: while the results of the individual from Mereto (EBA) are in line with those from Arano, clearly revealing a diet based on the consumption of $C_{3}$ cereal-type plants, the comparison with Olmo di Nogara and Sedegliano shows that the human group from Arano is excluded from the trend of diffusion of $\mathrm{C}_{4}$ plants, that are testified in the diet in Northern Italy between the Early and Middle Bronze Age. The two humans from Sedegliano (EBA) fall between values at Olmo and Arano so that a limited consumption of $\mathrm{C}_{4}$ plants may be supposed. At Olmo di Nogara, both animals and humans have the typical isotopic value associated with $\mathrm{C}_{4}$ plant intake.

If we consider the Early Bronze Age in the Mediterranean and more generally in southern Europe, the isotopic data at Arano fall within the general isotopic setting. The sites of Padru Jossu and Is Calitas (Sardinia, Italy; Lai et al., 2007), Singen (Germany; Koch and Kupke, 2012), Perachora and Makrigialos (Greece, Petroutsa et al., 2007; Triantaphyllou, 2001), Chantemerle, Machal and Le Tourteix (Auvergne, France; Goude et al., 2011; Herrscher et al., 2014) and Cova de la Pastora, Coveta del Frare, Castillejo del Bonete, Motilla de Azuer, and Balearic Islands (Spain; García Borja et al., 2013; McClure et al., 2011; Nájera Colino et al., 2010; Nájera et al., 2012; Salazar-García et al., 2013; Van Strydonck et al., 2005), all dated to the beginning of the Bronze Age, show similar carbon and nitrogen ranges, suggesting that $\mathrm{C}_{3}$ plants were a very significant nutritional source, typical of a temperate ecosystem. However, the moderate enrichment in ${ }^{13} \mathrm{C}$ for some sites

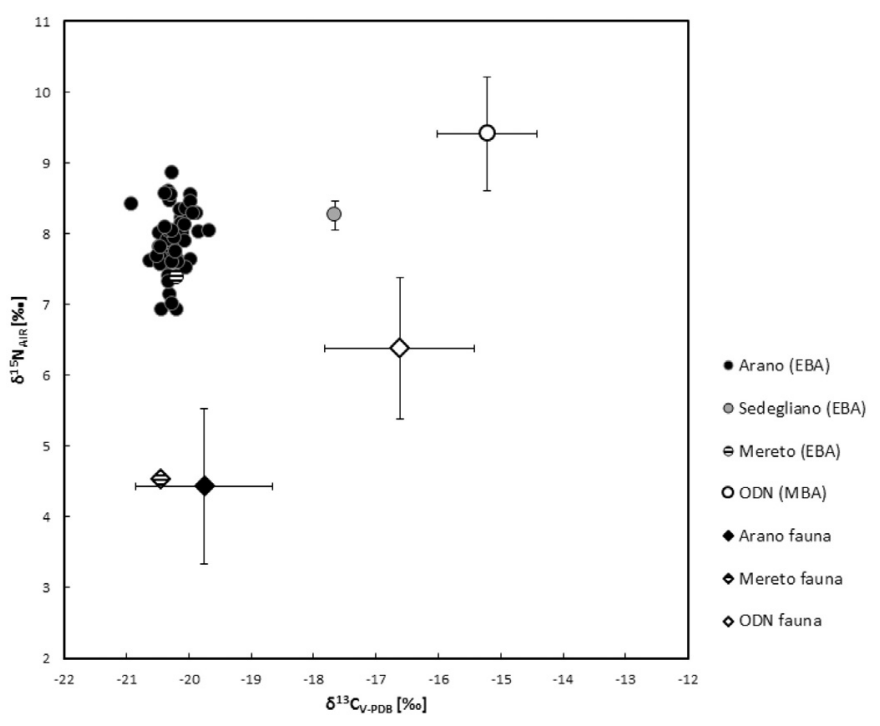

Fig. 4. Stable carbon and nitrogen isotope data of human and animal bone collagen from Arano di Cellore, compared with ranges from Olmo di Nogara (ODN), Sedegliano and Mereto. 
is due to the presence of a more arid local environment (e.g. Motilla de Azuer; López Sáez et al., 2014; Nájera Colino et al., 2010; Nájera et al., 2012). The contemporaneous absence (at Arano and Mereto) and sporadic presence (at Sedegliano) of isotopic evidence of $\mathrm{C}_{4}$ crop consumption, counteract the significant, full, shift to millets registered at Olmo di Nogara. This evidence suggests that the spread of $C_{4}$ plants in Northern Italy might have followed a complex pattern and might be placed in a narrow window at the transition between the end of the Early and the beginning of the Middle Bronze Age. The co-existence of different food practices in a relatively small area of the northern Peninsula over a short chronological interval could be associated with a discontinuous spread of the millets, which might have reached specific sites at very specific times through a 'leapfrog' dispersion. Many finds of millets seeds in several earlier sites have been registered confirming that this plant was already present in Italy, however nowhere had it been recorded as the prevailing crop in the floral assemblage. We cannot exclude that at the beginning it was solely used as animal fodder and later, for various reasons (e.g. climatic changes, decrease in soil productivity, see Cremaschi, 1997) the crop was used for human consumption too. Indeed, this evidence calls for a further isotopic and paleobotanical investigation, which could help identify the nature and complexity of this cultural phenomenon.

\section{Conclusions}

An extensive investigation of dietary practices through $\delta^{15} \mathrm{~N}$ and $\delta^{13} \mathrm{C}$ isotopic analysis is presented here for the population of Arano di Cellore. The results show that diet was mostly terrestrial, and relied on the consumption of $C_{3}$ crops. Even though social differences are evident in the archeological assemblages found in the graves, such complexity does not occur in terms of dietary intake, at least not in a way readable through nitrogen and carbon isotope analysis. In addition, no differences are registered between groups defined by gender, age at death, orientation of the body and position in the grave. Only a wider range of $\delta^{15} \mathrm{~N}$ for the males is noticed suggesting a more various diet. Beside the new evidence on dietary practices at a specific site in the Early Bronze Age, the isotopic analysis conducted at Arano significantly contributes to our understanding of the dynamics of introduction and spread of $\mathrm{C}_{4}$ plants in northern Italy. We propose that the transition between the Early and Middle Bronze Age represents a crucial moment for the foodways of the populations of northern of Italy. Among the possible causes for the adoption of $\mathrm{C}_{4}$ crops, environmental changes which led to increasing aridity of the soils is still a valid option (cf. Cremaschi et al., 2006, 2016; Valsecchi et al., 2006). The isotopic dataset from Arano further defines, in time and space, the pattern of diffusion of $\mathrm{C}_{4}$ plants in Italy, while opening new avenues of investigations.

\section{Acknowledgments}

We thank Luciano Salzani for providing the archeological background. We are grateful to Mike Hall and James Rolfe, of the Godwin Lab, Dept of Earth Sciences, University of Cambridge, for the help with isotopic analyses, and Catherine Kneale for the help in sample preparation and analysis. We also thank Tamsin $\mathrm{O}^{\prime}$ Connell, at the Dorothy Garrod Lab, University of Cambridge, for the access to lab facilities and discussion of the data. M.A.T. and J.M.C. designed the research. A.V. performed the isotopic analysis. A.V., M.A.T. and J.M.C. wrote the paper. I.D., S.B., and S.B., provided archeological and osteological information. This research was funded by MIUR and Marie-Curie IEF (235966) granted to M.A.T. The financial support of Regione Veneto - Ufficio valorizzazione Patrimonio Storico Archeologico is acknowledged. A.V. thanks the Centre of Excellence LabexMed - The human and social sciences at the interdisciplinary centre for the Mediterranean with the reference 10-LABX-0090 (ANR-11-IDEX-0001-02).

\section{References}

Baioni, M., 2000. La necropoli dell'antica età del Bronzo di Sorbara (Asola-MN). Quaderni di Archeologia del Mantovano. Vol. 2, pp. 41-90.

Bernabò Brea, M., Mazzieri, P., 2013. Nuovi dati sul campaniforme in Emilia. In: De Marinis, R.C. (Ed.), L'età del RameLa Pianura padana e le Alpi al tempo di Ötzi. La Compagnia della Stampa Massetti Rodella Editori, Brescia, pp. 503-524.

Bocherens, H., Drucker, D., 2003. Trophic level isotopic enrichment of carbon and nitrogen in bone collagen: case studies from recent and ancient terrestrial ecosystems. Int. J. Osteoarchaeol. 13, 46-53.

Bona, F., 2011. Il sito palafitticolo del Bronzo Antico del Lago Lucone (area D). In: Le Palafitte: Ricerca, Conservazione, Valorizzazione. Abstracs volume, pp. 29-32 (Desenzano del Garda, 6-8 October 2011)

Brothwell, D.R., 1963. The macroscopic dental pathology of some earlier human populations. In: Brothwell, D.R. (Ed.), Dental Anthropology. MacMillan, New York.

Brown, T.A., Nelson, D.E., Vogel, J.S., Southon, J.R., 1988. Improved collagen extraction by modified Longin method. Radiocarbon 30 (2), 171-177.

Carra, M.L., 2012. Per una storia della cerealicoltura in Italia settentrionale dal Neolitico all'Età del Ferro: strategie adattive e condizionamenti ambientali. Università degli Studi di Bologna (PhD Thesis)

Castiglioni, E., Motella De Carlo, S., Nisbet, R., 1998. Indagini sui resti vegetali macroscopici a Canàr. In: Balista, C., Bellintani, P. (Eds.), Canàr di San Pietro Polesine Vol. 2. Ricerche archeo-ambientali sul sito palafitticolo, Padusa, Quaderni, pp. 115-130.

Chisholm, B.S., Nelson, D.E., Schwarcz, H.P., 1982. Stable-carbon isotope ratios as a measure of marine versus terrestrial protein in ancient diets. Science 216 (4550), 1131-1132.

Cremaschi, M., 1997. Terramare e paesaggio padano. In: Bernabò Brea, M., Cardarelli, A. Cremaschi, M. (Eds.), Le TerramareLa più antica civiltà padana. Electa, Milano, pp. 107-125.

Cremaschi, M., Pizzi, C., Valsecchi, V., 2006. Water management and land use in the terramare and a possible climatic co-factor in their abandonment: the case study of the terramara of Poviglio Santa Rosa (northern Italy). Quat. Int. 151, 87-98.

Cremaschi, M., Mercuri, A.M., Torri, P., Florenzano, A., Pizzi, C., 2016. Climate change versus land management in the Po Plain (Northern Italy) during the Bronze Age: New insights from the VP/VG sequence of the Terramara Santa Rosa di Poviglio. Quat. Sci. Rev. 136, 153-172.

David, W., 1998. Zu früh- und ältermittelbronzezeitlichen Grabfunden in Ostbayern. In: Michálek, J., Schmotz, K., Zápotocká, M. (Eds.), Archäologische Arbeitsgemeinschaft Ostbayern/West- und Südböhmen. 7. Treffen (Landau an der Isar, 11-14 June 1997)Resümees Der Vorträge. Leidorf, Rahden, pp. 108-129.

David, W., 2002. Studien zu Ornamentik und Datierung der bronzezeitlichen Depotfundgruppe Hajdúsámson-Apa-Ighiel-Zajta. Bibliotheca Musei Apulensis XVIII. Altip, Alba Iulia.

David-Elbiali, M., 2011. À la recherche du guerrier dans les sépultures du Bronze ancien et moyen (2200-1300 av. J.C.) en Europe centre-occidentale et en Italie du Nord. In: Baray, L., Honegger, M., Dias-Meirinho, M.-H. (Eds.), L'armement et l'image du guerrier dans les sociétés anciennes: de l'object à la tombeActes de la Table ronde internationale et interdisciplinaire (Sens, 4-5 June 2009). Éditions Universitaires de Dijon, Dijon, pp. 189-224

David-Elbiali, M., David, W., 2009. Le Bronze ancien et le début du Bronze moyen: cadre chronologique et liens culturels entre l'Europe nord-alpine occidentale, le monde danubien et l'Italie du Nord. In: Richard, A., Barral, P., Daubigney, A., Kaenel, G., Mordant, C., Piningre, J.-F. (Eds.), L'isthme européen Rhin-Saône-Rhône dans la Protohistoire. Approches nouvelles en hommage à Jacques-Pierre MillotteActes Du Colloque (Besançon, 16-18 October 2006). Annales Littéraires 860. Presses Universitaires de Franche-Comté, Besançon, pp. 311-340.

De Grossi Mazzorin, J., Solinas, A., 2013. L'analisi dei resti faunistici provenienti dai settori A ed E della palafitta del Lavagnone. In: De Grossi Mazzorin, J., Curci, A., Giacobini, G. (Eds.), Le discipline bioarcheologiche per la ricostruzione del quadro economicoambientale dell'Italia padana nell'età del Bronzo, BACT 11. Edilpuglia, Bari, pp. 21-102.

De Marinis, R.C., 1999. Towards a relative and absolute chronology of the Bronze Age in Northern Italy. Not. Archeol. Bergomensi 7, 23-100.

DeNiro, M.J., 1985. Post-mortem preservation and alteration of in vivo bone collagen isotope ratios in relation to palaeodietary reconstruction. Nature 317, 806-809.

Dori, I., 2014. Storie sepolte: paleobiologia della popolazione di Arano. Studio antropologico di una comunità del Bronzo Antico. Università degli Studi di Firenze (PhD Thesis).

Dufour, E., Bocherens, H., Mariotti, A., 1999. Palaeodietary implications of isotopic variability in Eurasian lacustrine fish. J. Archaeol. Sci. 26, 617-627.

El-Najjar, M.Y., De Santi, M.V., Ozebek, L., 1978. Prevalence and possible etiology of dental enamel hypoplasia. Am. J. Phys. Anthropol. 48, 185-192.

Ferembach, D., Schwidetzky, I., Stloukal, M., 1980. Recommendations for age and sex diagnoses of skeletons. J. Hum. Evol. 9, 517-549.

Fiorentino, G., Castiglioni, E., Rottoli, M., Nisbet, R., 2004. Le colture agricole in Italia nel corso dell'età del Bronzo: sintesi dei dati e linee di tendenza. In: Viareggio, Lucca (Eds.), L'età del bronzo recente in Italia. Atti del Congresso Nazionale (Lido di Camaiore, 26-29 October 2000), Mauro Baroni, Viareggio, Lucca, pp. 219-226.

Forni, G., 1979. Origini delle strutture agrarie dell'Italia preromana: le grandi epoche dell'evoluzione agricola preistorica in Italia. Giannini, Napoli.

García Borja, P., Pérez Fernández, A., Biosca Cirujeda, V., Ribera i Gomes, A., Salazar-García, D.C., 2013. Los restos humanos de la Coveta del Frare (La Font de la Figuera, València). In: García Borja, P., Revert Francés, E., Ribera i Gomes, A., Biosca Cirujeda, V. (Eds.), El naixement d'un pobleHistòria i arqueologia de La Font de la Figuera. Ajuntament de la Font de la Figuera, pp. 47-61.

Goodman, A.H., Rose, J.C., 1990. Assessment of systemic physiological perturbations from dental enamel hypoplasias and associated histological structures. Yearb. Phys. Anthropol. 33, 59-110. 
Goodman, A.H., Rose, J.C., 1991. Dental enamel hypoplasias as indicators of nutritional status. In: Larsen, C.S., Kelley, M.A. (Eds.), Advances in Dental Anthropology. WileyLiss, New York, pp. 279-293.

Goodman, A.H., Armelagos, G.J., Rose, J.C., 1980. Enamel hypoplasias as indicators of stress in three prehistoric populations from Illinois. Hum. Biol. 52, 515-528.

Goude, G., 2007. Etude des modes de subsistance de populations néolithiques (VIe-IVe millénaires av. J.-C.) dans le nord-ouest de la Méditerranée. Approche par l'utilisation des isotopes stables $\left({ }^{13} \mathrm{C}\right.$ et $\left.{ }^{15} \mathrm{~N}\right)$ du collagène. Université Bordeaux 1-Université de Leipzig (PhD Thesis).

Goude, G., Lisfranc, R., Loison, G., Forest, V., Herrscher, E., 2011. The Bronze Age diet in Auvergne (France): a stable isotope approach. Am. J. Phys. Anthropol. 144 (S52), 195-196.

Hamilakis, Y., 1996. Wine, oil and the dialectics of power in Bronze Age Crete: a review of the evidence. Ox. J. Archaeol. 15, 1-32.

Harding, A.F., 2000. European Societies in the Bronze Age. Cambridge University Press, Cambridge.

Harding, A.F., Fokkens, H., 2013. The Oxford Handbook of the European Bronze Age. Oxford University Press, Oxford.

Hedges, R., Reynard, L., 2007. Nitrogen isotopes and the trophic level of humans in archaeology. J. Archaeol. Sci. 34, 1240-1251.

Herrscher, E., Goude, G., Lisfranc, R., Forest, V., Vermeulen, C., 2014. Pratiques alimentaires au Bronze ancien en Auvergne: Essai de restitution par l'analyse isotopique. In: Préhistoires Méditerranéennes [Online] 2013(4), online from the 29 August 2014, http://pm.revues.org/782

Hillson, S., 2001. Recording dental caries in archaeological human remains. Int. J. Osteoarchaeol. 11, 249-289.

Hunt, H.V., Vander Linden, M., Liu, X., Motuzaite-Matuzevicuite, G., Colledge, S., Jones, M.K., 2008. Millets across Eurasia: chronology and context of early records of the genera Panicum and Setaria from archaeological sites in the Old World. Veg. Hist. Archaeobot. 17 (Suppl.1), S5-S18.

Koch, J.K., Kupke, K., 2012. Life course-reconstruction of mobile individuals in an Early Bronze Age society in Central Europe. Concept of the project and first results to the cemetery of Singen (Germany). In: Kaiser, E., Burger, J., Schier, W. (Eds.), Population Dynamics in Prehistory and Early History New Approaches by Using Stable Isotopes and Genetics. De Gruyter, Berlin, Boston, pp. 225-240.

Krause, R., 1988. Die endneolithischen und frühbronzezeitlichen Grabfunde auf der Nordstadtterrasse von Singen am Hohentwiel. Forschungen und Berichte zur Vorund Frühgeschichte in Baden-Württemberg 32. Theiss, Stuttgart.

Lai, L., Tykot, R.H., Beckett, J.F., Floris, R., Fonzo, O., Usai, E., Manunza, M.R., Goddard, E., Hollander, D., 2007. Interpreting stable isotope analyses: case studies on Sardinian prehistory. In: Glascock, M.D., Speakman, R.J., Popelka-Filcoff, R.S. (Eds.), Archaeological Chemistry: Analytical Techniques and Archaeological Interpretation. American Chemical Society, Washington, DC, pp. 114-136.

Lai, L., Tykot, R.H., Usai, E., Beckett, J.F., Floris, R., Fonzo, O., Goddard, E., Hollander, D., Manunza, M.R., Usai, A., 2014. Diet in the Sardinian Bronze Age: models, collagen isotopic data, issues and perspectives. Préhistoires Méditerranéennes [Online] 2013(4), online from the 29 August 2014, http://pm.revues.org/795.

Lelli, R., Allen, R., Biondi, G., Calattini, M., Conati Barbaro, C., Gorgoglione, M.A., Manfredini, A., Martinez-Labarga, C., Radina, F., Silvestrini, M., Tozzi, C., Rickards, O., Craig, O., 2012. Examining dietary variability of the earliest farmers of south-eastern Italy. Am. J. Phys. Anthropol. 149, 380-390.

Lightfoot, E., Liu, X., Jones, M.J., 2013. Why move starchy cereals? A review of the isotopic evidence for prehistoric millet consumption across Eurasia. World Archaeol. 45 (4), 574-623.

Longin, R., 1971. New method of collagen extraction for radiocarbon dating. Nature 230, 241-242.

López Sáez, J.A., Alba, Sánchez F., Nájera Colino, T., Molina, González F., Pérez Díaz, S. Sabariego Ruiz, S., 2014. Paleoambiente y sociedad en la Edad del Bronce de La Mancha: la Motilla del Azuer. Cuadernos de Prehistoria y Arqueología de la Universidad de Granada. Vol. 24, pp. 391-422.

Marzatico, F., 2009. Le basi economiche dell'età del Bronzo in Italia settentrionale. In: Bartelheim, M., Stäuble, H. (Eds.), Die wirtschaftlichen Grundlagen der Bronzezeit Europas. The Economic Foundations of the European Bronze Age, rem. CurtEngelhorn-Zentrum Archäometrie gGmbH. Forschungen zur Archäometrie und Altertumswissenschaft Vol. 4, pp. 213-252.

Mayer, E.F., 1977. Die Äxte und Beile in Osterreich. Prähistorische Bronzefunde, Abt IX. Vol. 9.

McClure, S.B., Garcia García, O., Roca de Togores, C., Culleton, B.J., Kennett, D.J., 2011. Osteological and paleodietary investigation of burials from Cova de la Pastora, Alicante, Spain. J. Archaeol. Sci. 38, 420-428.

Meindl, R.S., Lovejoy, C.O., 1985. Ectocranial suture closure: a revised method for the determination of skeletal age at death based on lateral-anterior suture. Am. J. Phys. Anthropol. 68, 47-56.

Archeobotanica e alimentazione. In: Mercuri, A.M., Baroni, R., Mariotti Lippi, M. (Eds.), Workshop (Florence, 18 December 2006). Atti Soc. Nat. Mat. Modena Vol. 137.

Nájera Colino, T., Molina González, F., Jiménez-Brobeil, S.A., Sánchez Romero, M., Al Oumaoui, I., Aranda Jiménez, G., Delgado-Huertas, A., Laffranchi, Z., 2010. La población infantil de la Motilla del Azuer: Un estudio bioarqueológico. Complutum 21, 69-102.

Nájera, T., Jiménez-Brobeil, S.A., Molina, F., Delgado-Huertas, A., Laffranchi, Z., 2012. La aplicación de los métodos de la antropología física a un yacimiento arqueológico: La Motilla Del Azuer. Cuadernos de Prehistoria y Arqueología de la Universidad de Granada. Vol. 22, pp. 149-183.

Neugebauer, J.-W., 1991. Die Nekropole F von Gemeinlebarn, Niederösterreich. Untersuchungen zu den Bestattungssitten und zum Grabraub in der ausgehenden Frühbronzezeit in Niederösterreich südlich der Donau zwischen Enns und Wienerwald. Römisch- Germanische Forschungen 49. Von Zabern, Mainz am Rhein.
Neugebauer, Ch., Neugebauer, J.-W., 1997. Franzhausen: das Frühbronzezeitliche Gräberfeld I. Fundberichte aus ÖsterreichMaterialhefte Reihe A. Heft 5 Vols. 1-2. 2 volumes. Horn, Berger.

Nikiforuk, G., Fraser, D., 1981. The etiology of enamel hypoplasia: a unifying concept. J. Pediatr. 98, 888-893.

Nisbet, R., 1992. L'età del Bronzo in Italia nei secoli dal XVI al XIV A.C, in: L'età del Bronzo in Italia nei secoli dal XVI al XIV A.C. Rassegna di Archeologia 10, 172-173.

Nisbet, R., 1996. I cereali, le leguminose e i problemi della loro conservazione nell'Italia nord-occidentale dalla preistoria al XIII secolo. In: Comba, R., Panero, F. (Eds.), Il seme, l'aratro la messe. Soc. Studi Stor. Archeologici, Rocca dè Baldi, Cuneo, pp. 13-22

Nisbet, R., 2004. Agricoltura ed economia vegetale. In: De Marinis, R.C., Spadea, G. (Eds.), Liguri. Un antico popolo europeo tra Alpi e Mediterraneo. Skira, Milano, pp. 65-67.

Nisbet, R., Rottoli, M., 1997. Le analisi dei macroresti vegetali dei siti dell'età del Bronzo. In: Bernabò Brea, M., Cardarelli, A., Cremaschi, M. (Eds.), Le Terramare. La più antica civiltà padana. Electa, Milano, pp. 469-474.

O'Connell, T.C., Hedges, R.E.M., 1999. Investigations into the effect of diet on modern human hair isotopic values. Am. J. Phys. Anthropol. 108, 409-425.

Parker Pearson, M., 1999. The Archaeology of Death and Burial. Texas A\&M University Press, College Station.

Pernicka, E., Salzani, P., 2011. Remarks on the analyses and future prospects. In: Aspes, A (Ed.), I bronzi del Garda: valorizzazione delle collezioni di bronzi preistorici di uno dei più importanti centri metallurgici dell'Europa del II millennio a.C. Memorie del Museo Civico di Storia Naturale di Verona (2a serie). Sezione Scienze dell'Uomo 11, Verona, pp. 89-98.

Petroutsa, E.I., Richards, M.P., Manolis, S.K., 2007. Stable isotope analysis of human remains from the Early Helladic site of Perachora, Korinth, Greece. In: Mee, C. Renard, J. (Eds.), Cooking Up the Past: Food and Culinary Practices in the Neolithic and Bronze Age Aegean. Oxbow Books Ltd, Oxford, pp. 290-296.

Richards, M.P., Hedges, R.E.M., 1999. Stable isotope evidence for similarities in the types of marine foods used by Late Mesolithic humans at sites along the Atlantic coast of Europe. J. Archaeol. Sci. 26, 717-722.

Riedel, A., 1998. The Bronze Age animal bone deposit of Cànar (Rovigo). In: Balista, C. Bellintani, P. (Eds.), Canàr di San Pietro Polesine. Ricerche paleoambientali sul sito palafitticolo. Padusa, Quaderni 2, pp. 151-179, pp. 189-190.

Rose, J.C., 1977. Defective enamel histology of prehistoric teeth from Illinois. Am. J. Phys Anthropol. 46, 439-446.

Rottoli, M., 2001. Analisi archeobotaniche: i macroresti vegetali. In: Frontini, P. (Ed.), Castellaro del Vhò. Campagne di scavo 1996-1999. Settore Cultura Musei e Mostre Raccolte Archeologiche e Numismatiche, Comune di Milano, pp. 175-195.

Rottoli, M., 2007. Alcuni aspetti dell'agricoltura neolitica in Italia settentrionale. In: Mercuri, A.M., Baroni, R., Mariotti-Lippi, M. (Eds.), Archeobotanica e alimentazione. Workshop (Florence, 18 December 2006). Atti Soc. Nat. Mat Vol. 137, pp. 243-254.

Rowe, N., 1982. Dental caries. In: Steele, P.F. (Ed.), Dimensions of Dental Hygiene, third ed. Lea \& Febiger, Philadelphia, pp. 209-237.

Ruckdeschel, W., 1978. Die frühbronzezeitlichen Gräber Südbayerns. Ein Beitrag zur Kenntnis der Straubinger Kultur. Antiquitas Reihe Vol. 2, p. 11

Salazar-García, D.C., Benítez De Lugo Enrich, L.B., Álvarez García, H.J., Benito Sánchez, M., 2013. Estudio diacrónico de la dieta de los pobladores antiguos de Terrinches (Ciudad Real) a partir del análisis de isótopos estables sobre restos óseos humanos. Rev. Esp. Antrop. Fís. 34, 6-14.

Salzani, L., 1998/1999. Sepolture dell'antica età del Bronzo da Valserà di Gazzo Veronese (VR). Padusa 34-35, 63-75.

Salzani, L., 2001. Nuovi rinvenimenti da Valserà di Gazzo Veronese. Padusa 37, 69-82.

Salzani, P., 2011. I metalli del progetto "I bronzi del Garda": primi risultati e prospettive future. In: Aspes, A. (Ed.), I bronzi del Garda: valorizzazione delle collezioni di bronzi preistorici di uno dei più importanti centri metallurgici dell'Europa del II millennio a.C. Memorie del Museo Civico di Storia Naturale di Verona (2a serie). Sezione Scienze dell'Uomo 11, Verona, pp. 47-87.

Salzani, P., 2014. Il sito di Arano (Verona - scavi 2007) alla luce delle trasformazioni sociali, economiche, tecnologiche tra età del Rame e Bronzo Antico in Italia settentrionale. Università degli Studi di Trento (PhD Thesis).

Salzani, L., Salzani, P., 2008. Storie sepolte. Riti e culti all'alba del duemila avanti Cristo. Catalogo della mostra (Verona, 25 October 2008-30 June 2009). Comune di Verona, Assessorato alla Cultura, Museo Civico di Storia Naturale, MiBAC e Soprintendenza per i Beni Archeologici del Veneto.

Salzani, P., Salzani, L., Dori, I., Bortoluzzi, S., Boccone, S., Moggi Cecchi, J., 2015. La necropoli del Bronzo Antico di loc. Arano - Cellore di Illasi, Verona (2007). Studi di Preistoria e Protostoria 2. Preistoria e Protostoria in Veneto, pp. 289-294.

Schultz, M., 1988. Paläopathologosche Diagnostik. In: Knusmann, R. (Ed.), Antropologie Handbuch der vergleichenden Biologie des Menschen. Gustav Fischer Verlag, Stuttgart, pp. 480-496.

Schutkowski, H., 1993. Sex determination of infant and juvenile skeletons: I Morphognostic features. Am. J. Phys. Anthropol. 90, 199-205.

Seidemann, R.M., Stojanowski, C.M., Doran, G.H., 1998. The use of the supero-inferior femoral neck diameter as a sex assessor. Am. J. Phys. Anthropol. 107, 305-313.

Skinner, M., Goodman, A.H., 1992. Anthropological uses of developmental defects of enamel. In: Saunders, S.R., Katzenberg, M.A. (Eds.), Skeletal Biology of Past Peoples Research Methods. Wiley-Liss, New York, pp. 153-175.

Smith, B.H., 1984. Patterns of molar wear in hunter-gatherers and agriculturalist. Am. J. Phys. Anthropol. 63, 39-58.

Steckel, R.H., Larsen, C.S., Sciulli, P.W., Walker, P.L., 2006. Data Collection Codebook. The Global History of Health Project. State University, Ohio.

Tafuri, M.A., Craig, O.E., Canci, A., 2009. Stable isotope evidence for the consumption of millet and other plants in Bronze Age Italy. Am. J. Phys. Anthropol. 139 (2), 146-153.

Tafuri, M.A., Robb, J., Belcastro, M.G., Mariotti, V., Iacumin, P., Di Matteo, A., O'Connell, T. 2014. Herding practices in the ditched villages of the Neolithic Tavoliere (Apulia, 
South-east Italy). A vicious circle? The isotopic evidence. In: Whittle, A., Bickle, P. (Eds.), Early Farmers. The View from Archaeology and Science. Proceedings of the British Academy, 198. Oxford University Press, Oxford, pp. 143-158.

Torbrügge, W., 1959. Die Bronzezeit in Der Oberpfalz. Materialhefte zur Bayerischen Vorgeschichte, Reihe A 13. Kallmünz.

Triantaphyllou, S., 2001. A bioarchaeological approach to prehistoric cemetery populations from central and western Greek Macedonia. BAR International Series 976.

Ubelaker, D.H., 1989. Human Skeletal Remains: Excavation, Analysis, Interpretation. Taraxacum, Washington.

Valsecchi, V., Tinner, W., Finsinger, W., Ammann, B., 2006. Human impact during the Bronze Age on the vegetation at Lago Lucone (northern Italy). Veg. Hist. Archaeobot. $15,99-113$.

Valzolgher, E., Meadows, J., Salzani, P., Salzani, L., 2012. Radiocarbon dating of the Early Bronze Age cemetery at Arano, Verona, northern Italy. In: Boaretto, E., Rebollo Franco, N.R. (Eds.), Proceedings of the 6th International Radiocarbon and Archaeology Symposium (Pafos, Cyprus, 10-15 April 2011). Radiocarbon Vol. 54, pp. 483-503.
Van Klinken, G.J., 1999. Bone collagen quality indicators for palaeodietary and radiocarbon measurements. J. Archaeol. Sci. 26, 687-695.

Van Strydonck, M., Boudin, M., Ervynck, A., Orvay, J., Borms, H., 2005. Spatial and temporal variation of dietary habits during the prehistory of the Balearic Islands as reflected by ${ }^{14} \mathrm{C}, \delta^{15} \mathrm{~N}$ and $\delta^{13} \mathrm{C}$ analyses on human and animal bones. Mayurqa 30, 523-542.

Varalli, A., Goude, G., Del Lucchese, A., 2015a. Dal Neolitico all'Età del Ferro: indagine paleonutrizionale su alcune popolazioni della Liguria attraverso un approccio isotopico. Archeologia in Liguria, Nuova serie 5 (2012-2013) 11-19.

Varalli, A., Moroni, A., Moggi Cecchi, J., Goude, G., 2015b. Dietary variability during Bronze Age in central Italy: first results. Int. J. Osteoarchaeol. http://dx.doi.org/10.1002/oa. 2434 (in press).

Viciano, J., Alemán, I., D'Anastasio, R., Capasso, L., Botella, M.C., 2011. Odontometric sex discrimination in the Herculaneum sample (79 AD, Naples, Italy), with application to juveniles. Am. J. Phys. Anthropol. 145, 97-106. 